\title{
A Comparative Study of 100 Cases for Lignocaine and Bupivacaine as Spinal Anaesthetic Agent in Lscs in Combind Millitary Hospital in Mymensingh
}

\author{
Lt. Col. Apple Mahmud Anwar ${ }^{1 *}$, Lt. Col. Nasrin Hasan², Lt. Col. Abu Hasnat MD Habibur Rahman ${ }^{3}$
}

\author{
${ }^{1} \mathrm{DA}, \mathrm{MCPS}, \mathrm{CCD}$, Graded Spl in Anaesthesiology, Department of Aneasthesiology, CMH, Mymensingh, Bangladesh \\ ${ }^{2}$ FCPS, MCPS, Classified Gynaecologist, Department of Gynae and Obstratics, CMH, Mymensingh, Bangladesh \\ ${ }^{3} \mathrm{MPH}, \mathrm{MPHIL}, \mathrm{CO}, \mathrm{CMH}$, Mymensingh, Bangladesh
}

DOI: $10.36347 /$ sjams.2021.v09i01.007

| Received: 03.12.2020 | Accepted: 16.12.2020 | Published: 08.01.2021

*Corresponding author: Lt. Col. Apple Mahmud Anwar

\section{Abstract}

\section{Original Research Article}

One hundred ASA grade 1 and 2 female patients in combined military hospital in Mymensingh, aged from 18 to 40 years scheduled for caesarean section willing to accept regional anaesthesia were studied in two groups. Group A received $2 \mathrm{ml}$ of injection lignocaine hydrochloride $5 \%$ in $7.5 \%$ dextrose and Group B received $3 \mathrm{ml}$ of injection bupivacaine hydrochloride $0.5 \%$ in L3-L4 subarachnoid space. Statistically there was difference $(p<0.001)$ in onset of complete analgesia and its duration in these two drugs but clinically lignocaine produces better motor blockade than bupivacaine. Hypotension was observed with bupivacaine $(\mathrm{p}<0.001)$ whereas nausea and vomiting was prevalent with lignocaine. Lignocaine is found suitable for operation of shorter duration, whereas bupivacaine is suitable for operation lasting up to two and half hours, both the drugs were found safe, caused no significant complication.

Keyword: Lignocaine, bupivacaine, hypotension, bradycardia.

Copyright $\odot 2020$ The Author(s): This is an open-access article distributed under the terms of the Creative Commons Attribution 4.0 International License (CC BY-NC 4.0) which permits unrestricted use, distribution, and reproduction in any medium for non-commercial use provided the original author and source are credited.

\section{INTRODUCTION}

Spinal anaesthesia, the temporary interruption of nerve transmission following injection of a local anesthetic solution into the subarachnoid space, is a versatile and frequently employed method of regional anaesthesia in surgical and obstetrical as well as in management of certain pain problems. This regional anesthetic technique offers significant advantage over general anesthesia, the pharmacology of the local anesthetic agent as well as the physiologic changes that accompany these anesthetics, can anticipate any untoward side effects and enables to counter them efficiently. We have carried out this comparative study between lignocaine and bupivacaine as spinal anesthetic agents to find out the safety, reliability and acceptability of lignocaine hydrochloride.

\section{Materials AND MeTHOdS}

One hundred patients of ASA grade 1 and 2 aged from 18 to 40 years, scheduled for lower uterine caesarean section were studied. Patients with neurological disorders, spinal deformities, hypovolemia and coagulopathy were excluded from study. Patients were divided into two groups. Group A consisted of 50 patients, each patient received $2 \mathrm{ml}$ of lignocaine hydrochloride $5 \%$ in $7.5 \%$ dextrose and group B consisted of 50 patients and each patient received $3 \mathrm{ml}$ of injection bupivacaine hydrochloride $0.05 \%$ in $8 \%$ dextrose. Intravenous preloading of fluid was done before operation. During operation no analgesic or sedatives were given. Intravenous fluid given at the rate of $10 \mathrm{ml} / \mathrm{kg} /$ hour in addition to fluid loss. Monitoring of pulse and blood pressure were done at predetermined regular interval and also when desired. The patient was positioned in lying lateral and under aseptic condition drug was injected into the subarachnoid space between $\mathrm{L}_{3}-\mathrm{L}_{4}$ using 22 to 25 -gauge spinal needle. Onset and height of analgesia were determined by every minute pin prick method. The intensity of sensory and motor block were recorded as follows

A. Sensory block (Bromage grading) [1].
1. Excellent - full sensory blockade was achieved.

2. Good - full sensory blockade was adequate but sedation with diazepam and intravenous opiates were required to supplement the block.

3. Fair - block was not sufficient for operation and supplementation of volatile anesthetic agents were required.

B. Motor block (Bromage scale) [2]

1. Complete - unable to move legs or feet. 
Mahmud Anwar et al; Sch J App Med Sci, Jan, 2021; 9(1): 38-41

2. Almost complete - under to flex knee but still flexion of feet is possible.

3. Partial - just able to flex knee out still full flexion of feet possible.

4. 'O' block - full flexion of knee and feet possible.

\section{RESULT}

Hypotension was considered significant when systolic blood pressure drooped by $30 \%$ of the preanaesthetic level and was treated with rapid intravenous infusion. Vasopressor were kept in reserve for more severe cases. Significant bradycardia was considered when pulse rate was less than $60 / \mathrm{min}$ and was treated with injection prochlorparazine $12.5 \mathrm{mg}$ intramuscularly. Results were compiled and student`s ' $t$ ' test was used for statistical analysis. The $p<0.05$ was taken as level of statistical significance.

Table 1: Age distribution

\begin{tabular}{|l|l|l|l|l|}
\hline \multirow{2}{*}{ Age(years) } & \multicolumn{2}{l|}{ Lignocaine(n-50) } & \multicolumn{2}{l|}{ Bupivacaine(n-50) } \\
\cline { 2 - 5 } & Number & Percentage & Number & Percentage \\
\hline $21-25$ & 20 & 40 & 18 & 36 \\
\hline $26-30$ & 12 & 24 & 13 & 26 \\
\hline $31-35$ & 10 & 20 & 11 & 22 \\
\hline $36-40$ & 08 & 16 & 08 & 16 \\
\hline
\end{tabular}

Table-2: Time of onset of complete analgesia (in minutes)

\begin{tabular}{|l|l|l|l|l|l|l|l|l|l|l|l|l|l|l|l|}
\hline Time of onset in min & $\mathbf{0 2}$ & $\mathbf{0 3}$ & $\mathbf{0 4}$ & $\mathbf{0 5}$ & $\mathbf{0 6}$ & $\mathbf{0 7}$ & $\mathbf{0 8}$ & $\mathbf{0 9}$ & $\mathbf{1 0}$ & $\mathbf{1 2}$ & $\mathbf{1 3}$ & $\mathbf{1 4}$ & $\mathbf{1 5}$ & Mean \pm SD & Result \\
\hline $\begin{array}{l}\text { Lignocaine } \\
\text { (n-50) }\end{array}$ & 07 & 20 & 14 & 04 & 03 & - & 02 & - & - & - & - & - & - & $3.68 \pm 1.36$ & $\mathrm{P}<0.001$ \\
\hline $\begin{array}{l}\text { Bupivacaine } \\
\text { (n-50) }\end{array}$ & - & 05 & 08 & 13 & 05 & 05 & 02 & 03 & 06 & 01 & - & 01 & 01 & $6.42 \pm 2.85$ & \\
\hline
\end{tabular}

Table-3: Duration of analgesia (in minutes)

\begin{tabular}{|l|l|l|l|l|l|l|l|l|l|l|}
\hline Duration in min & $\mathbf{0 0 - 3 0}$ & $\mathbf{3 1 - 4 0}$ & $\mathbf{6 1 - 7 0}$ & $\mathbf{7 1 - 8 0}$ & $\mathbf{8 1 - 9 0}$ & $\mathbf{9 1 - 1 0 0}$ & $\mathbf{1 0 1 - 1 1 0}$ & $\mathbf{1 1 1 - 1 2 0}$ & Mean \pm SD & Result \\
\hline $\begin{array}{l}\text { Lignocaine } \\
(\mathrm{n}-50)\end{array}$ & 02 & 00 & 03 & 00 & 19 & 02 & 19 & 05 & $108.48 \pm 34.12$ & $\mathrm{P}<0.001$ \\
\hline $\begin{array}{l}\text { Bupivacaine } \\
(\mathrm{n}-50)\end{array}$ & 00 & 00 & 01 & 10 & 10 & 03 & 25 & 02 & $145.5 \pm 43.47$ & \\
\hline
\end{tabular}

Table-4: Degree of sensory block

\begin{tabular}{|l|l|l|l|l|}
\hline \multicolumn{4}{|l|}{ Lignocaine (n-50) } & \multicolumn{2}{|l|}{ Bupivacaine (n-50) } \\
\hline Grading & Number & Percentage & Number & Percentage \\
\hline Excellent & 43 & 86 & 47 & 94 \\
\hline Good & 04 & 08 & 01 & 02 \\
\hline Fair & 02 & 04 & 00 & 00 \\
\hline Poor & 01 & 02 & 02 & 04 \\
\hline
\end{tabular}

Table-5: Degree of motor block

\begin{tabular}{|l|l|l|l|l|}
\hline \multicolumn{2}{|l|}{ Lignocaine (n-50) } & \multicolumn{2}{l|}{ Bupivacaine (n-50) } \\
\hline Grading & Number & Percentage & Number & Percentage \\
\hline Complete & 45 & 90 & 44 & 88 \\
\hline Almost complete & 03 & 06 & 03 & 06 \\
\hline Partial & 02 & 04 & 03 & 06 \\
\hline No block & 00 & 00 & 00 & 00 \\
\hline
\end{tabular}

Table-6: Systolic blood pressure changes

\begin{tabular}{|l|l|l|l|l|l|l|l|l|l|}
\hline $\begin{array}{l}\text { Fall of BP } \\
\text { (mm of Hg) }\end{array}$ & $\mathbf{0 0 - 1 0}$ & $\mathbf{1 1 - 2 0}$ & $\mathbf{2 1 - 3 0}$ & $\mathbf{3 1 - 4 0}$ & $\mathbf{4 1 - 5 0}$ & $\mathbf{5 1 - 6 0}$ & $\mathbf{6 1 - 7 0}$ & Mean \pm SD & Result \\
\hline $\begin{array}{l}\text { Lignocaine } \\
\text { (n-50) }\end{array}$ & 09 & 15 & 14 & 10 & 00 & 02 & 00 & $22.01 \pm 12.35$ & $\mathrm{P}>0.05$ \\
\hline $\begin{array}{l}\text { Bupivacaine } \\
\text { (n-50) }\end{array}$ & 07 & 10 & 10 & 12 & 04 & 04 & 03 & $29.43 \pm 17.12$ & \\
\hline
\end{tabular}


Mahmud Anwar et al; Sch J App Med Sci, Jan, 2021; 9(1): 38-41

Table-7: Diastolic blood pressure changes

\begin{tabular}{|l|l|l|l|l|l|l|l|l|l|}
\hline $\begin{array}{l}\text { Fall of BP } \\
\text { (mm of Hg) }\end{array}$ & $\mathbf{0 0 - 1 0}$ & $\mathbf{1 1 - 2 0}$ & $\mathbf{2 1 - 3 0}$ & $\mathbf{3 1 - 4 0}$ & $\mathbf{4 1 - 5 0}$ & $\mathbf{5 1 - 6 0}$ & $\mathbf{6 1 - 7 0}$ & Mean \pm SD & Result \\
\hline $\begin{array}{l}\text { Lignocaine } \\
(\mathrm{n}-50)\end{array}$ & 24 & 12 & 11 & 03 & 00 & 00 & 00 & $13.86 \pm 9.91$ & $\mathrm{P}>0.005$ \\
\hline $\begin{array}{l}\text { Bupivacaine } \\
(\mathrm{n}-50)\end{array}$ & 15 & 11 & 13 & 09 & 01 & 01 & 00 & $19.95 \pm 12.83$ & \\
\hline
\end{tabular}

Table-8: Heart range changes

\begin{tabular}{|l|l|l|l|l|l|l|}
\hline $\begin{array}{l}\text { Fall of heart rate } \\
\text { (Beat/min) }\end{array}$ & $\mathbf{0 0 - 1 0}$ & $\mathbf{1 1 - 2 0}$ & $\mathbf{2 1 - 3 0}$ & $\mathbf{3 1 - 4 0}$ & Mean \pm SD & Result \\
\hline $\begin{array}{l}\text { Lignocaine } \\
\text { (n-50) }\end{array}$ & 21 & 23 & 04 & 02 & $12.69 \pm 7.98$ & $\mathrm{P}>0.05$ \\
\hline $\begin{array}{l}\text { Bupivacaine } \\
(\mathrm{n}-50)\end{array}$ & 19 & 19 & 10 & 02 & $14.31 \pm 8.83$ & \\
\hline
\end{tabular}

Table-9: Perioperative and postoperative complications

\begin{tabular}{|l|l|l|l|l|}
\hline $\begin{array}{l}\text { Lignocaine } \\
\text { (n-50) }\end{array}$ & Number & Percentage & $\begin{array}{l}\text { Number } \\
\text { (n-50) }\end{array}$ & Percentage \\
\hline Complications & 06 & 12 & 03 & 06 \\
\hline Nausea & 04 & 08 & 02 & 04 \\
\hline Vomiting & 00 & 00 & 00 & 00 \\
\hline Restlessness & 00 & 00 & 00 & 00 \\
\hline Unconsciousness & 00 & 00 & 00 & 00 \\
\hline Retention of urine & 00 & 00 & 00 & 00 \\
\hline Headache & 00 & 00 & 00 & 00 \\
\hline Backache & 00 & 00 & 00 & 00 \\
\hline Neurological sequel & 02 & 04 & 05 & 10 \\
\hline Shivering & 00 & 00 & 00 & 00 \\
\hline Respiratory arrest & & & & \\
\hline
\end{tabular}

Table 1 shows age distribution. Out of one hundred patient age ranged from 20 to 40 year in Group A about $40 \%$ of patients were between 21 to 25 years age, $24 \%$ of patients were $26-30$ years age, $20 \%$ between $31-35$ years and $16 \%$ between $36-40$ years. In Group B about $36 \%$ of patients were between $21-25$ years, $26 \%$ of patients were $26-30$ years, $22 \%$ between $31-35$ years and $16 \%$ between $36-40$ years. Table 2 shows time onset of complete analgesia by both drugs. Lignocaine took 2 to 8 minutes, the mean value $3.8+1.36$ minutes and bupivacaine required 5 to 13 minutes, the mean value being $6.42+2.85$ minutes. The difference is statistically significant $(\mathrm{p}<0.001)$ lignocaine being of rapid onset than bupivacaine. Table 3 shows duration of analgesia. It is observed that the mean time of lignocaine is $108.48+43.47$ minutes and of bupivacaine is 145.5 +43.47 minutes. Difference is statistically significant $(p<0.001)$. Table 4 shows degree of sensory block. "Excellent"' result obtained with lignocaine in $86 \%$ of patients and with bupivacaine $94 \%$ of patients. Table 5 shows degree of motor block. Complete block obtained with lignocaine in $90 \%$ and with bupivacaine it is $88 \%$. The difference is insignificant. Table 6 shows changes of systolic blood pressure. the mean fall of blood pressure with lignocaine is $22.01+12.35 \mathrm{~mm} \mathrm{Hg}$ and with bupivacaine is $29.43+17.12 \mathrm{~mm} \mathrm{Hg}$ ( $\mathrm{p}>0.05)$. Fall of blood pressure more than $30 \mathrm{~mm} \mathrm{Hg}$ is more common with bupivacaine. Changes of diastolic blood pressure is shown in Table 7. Table 8 shows effect of drug on heart rate. The mean fall of heart rate was $14.31+8.83$ beat $/$ min with lignocaine $(p>0.05)$ Table 9 shows per-operative and immediate post-operative complications. Nausea and vomiting is common with lignocaine then bupivacaine. Shivering occurred in 04\% of patient with lignocaine and $10 \%$ patient with bupivacaine.

\section{DISCUSSION}

One hundred patients were studied to compare the action of lignocaine hydrochloride with bupivacaine hydrochloride in spinal anesthesia. We have found that there is significant difference in the time onset of analgesia between these two drugs. This is not in conformation of findings by Singh NP et al. who could not detect any significant deference in this regard [3]. In the mean duration of analgesia the findings are comparable with those of Moor et al., Covino et al., Chowdhury M A et al. and Sachdeva et al. [4-6]. This shows that bupivacaine gives analgesia for about two hours whereas lignocaine gives analgesia for about 1hour. About $86 \%$ of patient with lignocaine and $94 \%$ patient with bupivacaine showed satisfactory sensory blockage. These findings are in corroboration with those of Maître and Pramanik [7]. It can be inferred that bupivacaine produces better sensory block then lignocaine. Complete motor block obtained with 
lignocaine in $90 \%$ of patients and with bupivacaine in $88 \%$ of patients which is comparable to Shah et al. [8]. Fall in excess of $30 \%$ of original blood pressure was more common with bupivacaine then lignocaine. Arterial hypotension after spinal anaesthesia is common. It is caused at least in part by a decrease in total peripheral resistance as a result of sympathetic denervation. Fall of heart rate occurs with both the drugs but the difference is statistically insignificant. Incidence of bradycardia occurred only in 02 cases. Smith and Barton in their study mentioned almost all patients had nausea and vomiting along with hypotension and bradycardia [9]. In this study 6 patient had nausea and 4 patent vomited with lignocaine whereas 03 patient had nausea and 2 patient vomited with bupivacaine they responded well with reassurance and injection prochlorparazine. $12.5 \quad \mathrm{mg}$ intramuscularly. During operation 2 patients with lignocaine and 05 patients with bupivacaine developed shivering due to fall of body temperature because of cutaneous vasodilatation. Headache is the major complication of spinal block. In this study majority of spinal punctures were with 25-gauge spinal needles and a few cases with 22 gauge needle. None of the cases developed post dural puncture headaches (PDPH). Shutt $\mathrm{L} E$ et al. in their study found that the use of 22 and 25 gauge needle is associated with a low incidence of PDPH [10].

\section{COCNCLUSION}

In this study we can conclude that lignocaine is found suitable for operation of shorter duration, whereas bupivacaine is suitable for operation lasting up to two and half hours, both the drugs were found safe, caused no significant complication.

\section{REFERENCES}

1. Bromage PR. A comparison of hydrochloride and carbon dioxide salt of lignocaine and prilocaine in epidural analgesia. Acta Anaesthesiol Scand (supple). 1965, 16:55.

2. Cousines MJ, Bridenbaugh PO. Neural blockade. Philaelphia; JB Lippincott Co. 1980: 151,153,231.

3. Singh NP, Das CR, Agrawal AR. A comparative evaluation of newer local anelegsic drugs, bupivacaine, mapivacaine with lignocaine for spinal epidural anaesthesia. Indian Journal of Anaesth. 1970; 18:142.

4. Moore D, Bridenbagh MD, Bupicaine hydrochloride laboratory study. Anaesthesiology. 1970; 32: 78.

5. Covino BG. Comparative clinical pharmacology of local anaesthetic agents, Anaesthesiology. 1971, 36:162.

6. Sachdeva CK, bhandori SC, tendon M. Bupivacaine and Lignocaine in epidural analgesia for TUR-A comparative study. Indian journal of anaesthesia. 1981, 29:55.

7. Maitra S, Pramanik S. Role of continuous lumbar epidural analgesia in the management of pregnancy as compared to conventional methods. Indian journal of anaesthesia. 1079, 24:130

8. Shah K. Shah R, karndev VL. A omparative clinical study of bupivacaine and lignocaine I religion analgesia. Indian journal of anaesthesia. 1975, 23:28.

9. Smith GB, Barton FI, Watt JM. Extensive spred of local anesthetic solution following subdural insertion of an epidural catheter. Journal of japan society of anesthesiology. 1984, 39: 335

10. Shutt LE, Valentine SG, Wee MYK comparison of 22 and 25 gauge. Whitacre needle with 26 gauge quince needle. Brj anath. 1992, 69: 589-94. 